\title{
Extent of Adoption of Recommended Interventions of Groundnut crop among the Beneficiary and Non-beneficiary Respondents of National Mission on Oilseed and Oil Palmin Bikaner District of Rajasthan, India
}

\author{
Amit Kumar ${ }^{1 *}$, L.S. Bareth ${ }^{1}$, J.P. Yadav ${ }^{2}$, Manmeet Kaur $^{1}$ and Ramdhan Ghaswa ${ }^{3}$ \\ ${ }^{1}$ Department of Extension Education, COA, SKRAU, Bikaner, Rajasthan, India \\ ${ }^{2}$ Department of Extension Education, SKNCOA, SKNAU, Jobner, Rajasthan, India \\ ${ }^{3}$ Extension Education, KVK, Ratlam, Madhyapradesh-India \\ *Corresponding author
}

\section{A B S T R A C T}

Keywords

Adoption,

Interventions,

Beneficiary

respondents, Non-

beneficiary

respondents,

NMOOP

Article Info

Accepted:

18 July 2019

Available Online:

10 August 2019
The present study was conducted in Sri Dungargarh and Bikaner panchayat samities of Bikaner district of Rajasthan. Two villages were selected from each selected panchayat samiti and 20 beneficiary and the equal number of non-beneficiary respondents were selected randomly from each selected village for the study. Data were collected through the pre-structured interview schedule. The findings revealed that the majority of the total groundnut growers, 66.88 percent of respondents belonged to middle age group, 71.88 percent of respondents belonged to other backward castes, 33.75 percent were in the category of senior secondary education level and 65.62 percent of respondents had a large size of land holding (more than 4 ha), 54.38 percent of the respondents belonged to joint families, 58.75 percent of respondents were from large families having more than five members, 49.38 percent of groundnut respondents were member of any organization. The majority of the beneficiary and non-beneficiary respondents belonged to a medium level of adoption category. It was found that there was a significant difference in the level of adoption between the beneficiary and non-beneficiary respondents about recommended groundnut interventions.

\section{Introduction}

The Indian agriculture is the back bone of Indian economy. About 75 percent of its population and 66.67 percent of labor force directly or indirectly is dependent on agriculture for livelihood. Large number of important industries like jute, textiles, edible oils, tobacco, sugar etc. receives the raw materials produced by agriculture sectors. India is one of the major oil seeds grower and importer of edible oils. India's vegetable oil economy is world's fourth largest after USA, China and Brazil. National Mission on Oilseeds and Oil Palm (NMOOP) launched during 2014-15 envisages increasing production and productivity of oilseeds crops and oil palm through bringing in fallow areas under oilseed crops and diversification of area from low yielding cereals. It aims to achieve the required target by addressing major constraints to crop productivity through 
promotion of relevant technological interventions.

\section{Materials and Methods}

The present study was conducted in Bikaner district Rajasthan. Bikaner district has been selected purposely. Bikaner district comprises of six panchayat samities. Out of sixpanchayat samities, two panchayat samities were selected for present study on the basis of higher area and production of groundnut and NMOOP scheme was also operated in these panchayat samities. Presently, two villages from each selected panchayat samiti were selected randomly for the study purpose. Thus, there were four villages from two panchayat samities.For selection of beneficiary respondents, a comprehensive list of groundnut growers who were benefitted under National Mission on Oilseeds and Oil Palm. As mentioned earlier, from each villages 20 beneficiary and equal number of non-beneficiary farmers were selected randomly separately. Thus, total 80 beneficiary and 80 non-beneficiary farmers were selected for the study.

To measure the extent of adoption of respondents, anadoption scale was developed for this study. The adoption scale of groundnut crop had 44 items. Weightage was given to each item. The possible maximum score one could obtain was 100 . The mean and standard deviation of the entire respondent's adoption score was computed for classifying the adoption in low, medium and high categories. To determine the extent of adoption of respondents about each major aspect mean percent score was worked out and ranked accordingly. Besides, to find out the significance of the difference in adoption between different categories of respondents, Z-test was applied and conclusions were drawn accordingly.

\section{Results and Discussion}

The results obtained from the present study as well as discussions have been summarized under the following heads:

\section{Personal profile of the respondents}

Data presented in Table 1 depict that out of total groundnut growing respondents, 66.88 percent respondents belonged to middle age group, while 19.37 percent respondents belonged to old age group and 13.75 percent respondents were found, young age group. Further 77.50 percent beneficiary and 56.25 percent non-beneficiary farmers to be were from the middle age group. Whereas, 8.75 percent beneficiary and 18.75 percent nonbeneficiary farmers belonged to young age group. The representation of the old age group the beneficiary and non-beneficiary farmers were found to be 13.75 and 25.00 percent respectively. 71.88 percent of respondents belonged to other backward castes, while 16.88 percent of respondents belonged to the general caste and 11.25 percent were scheduled caste/scheduled tribe. Table 1 further shows that 77.50 percent beneficiary and 66.25 percent non-beneficiary belonged to other backward castes, while 10.00 percent beneficiary and 23.75 percent non-beneficiary belonged to the general caste and 12.50 beneficiary and 10.00 percent nonbeneficiary were scheduled caste/scheduled tribe. Further, Table 1 shows that 6.25 percent respondents were illiterate, 11.88 percent were educated from up to the primary level. Similarly, 15.62, 19.37 and 33.75 percent respondents were in the category of middle, Secondary, Sr. secondary. Whereas, the remaining 13.13 percent groundnut growers were educated up to graduate and above level in the study area. Further Table 1 shows that 5.00 percent beneficiary and 7.50 percent non-beneficiary were illiterate, 10.00 percent beneficiary and 13.75 percent non-beneficiary were educated from up to primary level. Similarly, 15.00, 18.75 and 36.25 percent groundnut beneficiary and 16.25, 20.00 and 31.25 percent of non-beneficiary were in the 
category of middle, secondary and $\mathrm{Sr}$. secondary. Whereas, remaining 15.00 percent beneficiary and 11.25 percent non-beneficiary were educated up to graduate and above the level.

Further analysis of Table 1 reveals that in the case of beneficiary farmers, 67.50 percent had large land holding, followed by 32.50 percent of them having medium land holding. Whereas, 63.75 percent of non-beneficiary had large land holding followed by 36.25 percent of them having a medium land holding. Further out of total groundnut respondents 65.62 percent had large size of land holding (more than 4 ha), followed by 34.38 percent of them having medium land holding (2-4 ha), It was interesting to note that none of the beneficiary as well as nonbeneficiary farmers fell in the category of small land holding.

From the results, it can be concluded that above 60.00 percent of respondents possessed more than 4 hectares land holding in the study area. Further analysis of data reveals that 54.38 percent of the total groundnut respondents belonged to joint families and the remaining 45.62 percent of respondents belonged to the families which are nuclear in composition. It was further noted that 51.25 percent beneficiary and 57.50 percent nonbeneficiary farmers were from the joint family group, whereas, 48.75 percent beneficiary and 42.50 percent non-beneficiary respondents were found in nuclear family group. It is interesting to note that still above 50.00 percent of farmers from both categories were maintaining the joint family concept in the villages.

Also indicate that 58.75 percent of respondents were from large families having more than five members. While remaining 41.25 percent of respondents were from small families having up to 5 members. Further, 65.00 percent of beneficiary and 52.50 percent non-beneficiary farmers have belonged to large size family groups. While 35.00 percent beneficiary and 47.50 percent non-beneficiary were categorized in small size of the family group.

The data recorded that 49.38 percent respondents were a member of any organization, whereas 38.13 percent respondents had no member of any organization and remaining 12.50 percent were reported office bearer of some organizations. It was also found that 50.00 percent beneficiary and 48.75 percent nonbeneficiary farmers had a member of any organization. Whereas, the beneficiary and non-beneficiary farmers who possessed no member of any organization to be 36.25 and 40.00 percent, respectively. It was further noted that 13.75 and 11.25 percent beneficiary and non-beneficiary farmers were reported office bearer of some organizations, respectively.

These findings are in line with the findings of Asiwal (2004) found that majority of $(83.33 \%)$ the respondents were young to middle age group, it was further found that majority of $(58.34 \%)$ belonged to high caste and more than half of the respondents 60.67 percent were literate, medium size of land holding 55.41 percent, 54.17 percent respondent belonged to nuclear family type, more than half 56.25 percent of the respondents were having large family size and more than two third of the respondents 76.25 percent were taking part in social activities. Similar findings are also reported by Salunkhe, et al., (2012), Kumar, A. (2013) and Raghuwanshi (2018).

Distribution of respondents according to their level of adoption about groundnut interventions

Data reported in Table 2 reveals that 57.50 percent beneficiary and 62.50 percent nonbeneficiary farmers were in a medium level of 
adoption category. Whereas, 17.50 percent beneficiary and 23.75 percent non-beneficiary respondents were found in the low level of adoption category. Likewise, 25.00 percent and 13.75 percent beneficiary and nonbeneficiary farmers possessed a high level of adoption respectively about recommended interventions of groundnut. Further, among the categories of groundnut growers, it was observed that 60.00 percent of the total respondents were in the medium level of adoption category, whereas, 20.62 percent respondents were in the low level of adoption category and remaining 19.38 percent groundnut growers to be observed in the high level of adoption about recommended interventions of groundnut. Similar findings are reported by Hadiya et al., (2014) observed that majority of 65.83 per cent respondents had medium adoption about the recommended practices of groundnut cultivation. Whereas, 19.17 per cent had low and 15.00 per cent had high extent of adoption of recommended practices of groundnut cultivation.

\section{Extent of Adoption of Beneficiary and Non-beneficiary Respondents Regarding Groundnut Intervention}

The interventions related to soil and field preparation, soil treatment, high yielding varieties, seed treatment, sowing time, seed rate and spacing, fertilizer application, irrigation management, weed management, plant protection measures and harvesting, threshing and storage were introduced under National Mission on Oilseed and Oil Palm in the study area. Therefore, an effort was made to assess the intervention wise extent of adoption among groundnut growers. The results have been given in the Table 3 .

Data depicted in Table 3 indicate that the extent of adoption of groundnut beneficiary respondents, the interventions like 'high yielding verities', 'Harvesting, threshing and storage', 'Time of sowing, seed rate and spacing', 'Field preparation', 'Seed treatment' and 'Manure and fertilizer application' were adopted with 100, 84.06, 82.08, 80.31, 77.19 and 74.84 MPS and given rank $1^{\text {st }}, 2^{\text {nd }}, 3^{\text {rd }}, 4^{\text {th }}$, $5^{\text {th }}$ and $6^{\text {th }}$ respectively. They possessed the medium level of adoption in the interventions like 'Irrigation management' (69.38 MPS), 'Plant protection measure' (60.21 MPS) and 'Weed management' (58.33 MPS) and assigned rank $7^{\text {th }}, 8^{\text {th }}$, and $9^{\text {th }}$ respectively. The intervention which was least adopted by them was 'Soil treatment' (48.75 MPS).

In case of non- beneficiary respondents, the interventions like 'high yielding verities', 'Time of sowing, seed rate and spacing', 'Harvesting, threshing and storage' and 'field preparation' were adopted with 100, 78.33, 78.13 and 76.25 MPS and given rank $1^{\text {st }}, 2^{\text {nd }}$, $3^{\text {rd }}$ and $4^{\text {th }}$ respectively.

Similarly they had medium adoption level in the interventions like 'Manure and fertilizer application' (67.03 MPS), 'Seed treatment' (65.94 MPS) and 'Plant protection measure' (54.38 MPS), 'Irrigation management' (53.13 MPS) and 'Weed management' (49.58 MPS) and ranked at $5^{\text {th }}, 6^{\text {th }}, 7^{\text {th }}, 8^{\text {th }}$ and $9^{\text {th }}$ places respectively. The least adopted intervention by them was 'Soil treatment' (35.15 MPS). The overall extent of adoption of the groundnut beneficiary respondents (73.52 MPS) was higher than the non-beneficiary respondents (65.79 MPS).

The value of calculated rank correlation $\left(r_{s}\right)$ was 0.96 which shows positive and significant at 1 percent level of significance, leading to conclusion that there was a similarity in the rank assigned pattern of adoption level of beneficiary and non-beneficiary groundnut respondents about groundnut production technology, though there was a difference in magnitude of Mean Percent Score of beneficiary and non-beneficiary respondents. 
Table.1 Distribution of respondents according to their personal attributes

\begin{tabular}{|c|c|c|c|c|}
\hline S. No. & Personal attributes & $\begin{array}{c}\text { Beneficiary } \\
(n=80)\end{array}$ & $\begin{array}{c}\text { Non-beneficiary } \\
(\mathbf{n}=\mathbf{8 0})\end{array}$ & $\begin{array}{c}\text { Total } \\
(\mathbf{n}=160)\end{array}$ \\
\hline 1 & Age Group & $\begin{array}{l}\mathbf{F} \\
(\%)\end{array}$ & $\begin{array}{c}\mathbf{F} \\
(\%)\end{array}$ & $\begin{array}{c}F \\
(\%)\end{array}$ \\
\hline i. & $\begin{array}{l}\text { Young } \\
\text { (Upto } 32 \text { years) }\end{array}$ & $\begin{array}{c}7 \\
(8.75)\end{array}$ & $\begin{array}{c}15 \\
(18.75)\end{array}$ & $\begin{array}{c}22 \\
(13.75)\end{array}$ \\
\hline ii. & $\begin{array}{l}\text { Middle } \\
\text { ( } 33 \text { to } 52 \text { years) }\end{array}$ & $\begin{array}{c}62 \\
(77.50)\end{array}$ & $\begin{array}{c}45 \\
(56.25)\end{array}$ & $\begin{array}{c}107 \\
(66.88)\end{array}$ \\
\hline iii. & $\begin{array}{l}\text { Old } \\
\text { (Above } 52 \text { years) }\end{array}$ & $\begin{array}{c}11 \\
(13.75)\end{array}$ & $\begin{array}{c}20 \\
(25.00)\end{array}$ & $\begin{array}{c}31 \\
(19.37)\end{array}$ \\
\hline 2 & Caste & & & \\
\hline i. & General & $\begin{array}{c}8 \\
(10.00)\end{array}$ & $\begin{array}{c}19 \\
(23.75)\end{array}$ & $\begin{array}{c}27 \\
(16.88)\end{array}$ \\
\hline ii. & OBC & $\begin{array}{c}62 \\
(77.50)\end{array}$ & $\begin{array}{c}53 \\
(66.25)\end{array}$ & $\begin{array}{c}115 \\
(71.88)\end{array}$ \\
\hline iii. & $\mathrm{SC} / \mathrm{ST}$ & $\begin{array}{c}10 \\
(12.50)\end{array}$ & $\begin{array}{c}8 \\
(10.00)\end{array}$ & $\begin{array}{c}18 \\
(11.25)\end{array}$ \\
\hline 3 & Education Level & & & \\
\hline i. & Illiterate & $\begin{array}{c}4 \\
(5.00)\end{array}$ & $\begin{array}{c}6 \\
(7.50)\end{array}$ & $\begin{array}{c}10 \\
(6.25)\end{array}$ \\
\hline ii. & upto primary & $\begin{array}{c}8 \\
(10.00)\end{array}$ & $\begin{array}{c}11 \\
(13.75)\end{array}$ & $\begin{array}{c}19 \\
(11.88)\end{array}$ \\
\hline iii. & Middle & $\begin{array}{c}12 \\
(15.00)\end{array}$ & $\begin{array}{c}13 \\
(16.25)\end{array}$ & $\begin{array}{c}25 \\
(15.62)\end{array}$ \\
\hline iv. & Secondary & $\begin{array}{c}15 \\
(18.75)\end{array}$ & $\begin{array}{c}16 \\
(20.00)\end{array}$ & $\begin{array}{c}31 \\
(19.37)\end{array}$ \\
\hline $\mathbf{v}$ & Sr. secondary & $\begin{array}{c}29 \\
(36.25)\end{array}$ & $\begin{array}{c}25 \\
(31.25)\end{array}$ & $\begin{array}{c}54 \\
(33.75)\end{array}$ \\
\hline vi. & Graduate and above & $\begin{array}{c}12 \\
(15.00)\end{array}$ & $\begin{array}{c}9 \\
(11.25)\end{array}$ & $\begin{array}{c}21 \\
(13.13)\end{array}$ \\
\hline 4 & Size of Land holding & & & \\
\hline i. & Small farmer (Less than $2 \mathrm{ha}$ ) & $\begin{array}{c}0 \\
(0.00)\end{array}$ & $\begin{array}{c}0 \\
(0.00)\end{array}$ & $\begin{array}{c}0 \\
(0.00)\end{array}$ \\
\hline ii. & Medium farmer (2 to 4 ha) & $\begin{array}{c}26 \\
(32.50)\end{array}$ & $\begin{array}{c}29 \\
(36.25)\end{array}$ & $\begin{array}{c}55 \\
(34.38)\end{array}$ \\
\hline iii. & Large farmer (More than 4 ha) & $\begin{array}{c}54 \\
(67.50)\end{array}$ & $\begin{array}{c}51 \\
(63.75)\end{array}$ & $\begin{array}{c}105 \\
(65.62)\end{array}$ \\
\hline 5 & Family Type & & & \\
\hline i. & Nuclear & $\begin{array}{c}39 \\
(48.75)\end{array}$ & $\begin{array}{c}34 \\
(42.50)\end{array}$ & $\begin{array}{c}73 \\
(45.62)\end{array}$ \\
\hline ii. & Joint & $\begin{array}{c}41 \\
(51.25)\end{array}$ & $\begin{array}{c}46 \\
(57.50)\end{array}$ & $\begin{array}{c}87 \\
(54.38)\end{array}$ \\
\hline 6 & Family Size & & & \\
\hline i. & Small (upto 5 members) & $\begin{array}{c}28 \\
(35.00)\end{array}$ & $\begin{array}{c}38 \\
(47.50)\end{array}$ & $\begin{array}{c}66 \\
(41.25)\end{array}$ \\
\hline ii. & Large (Above 5 members) & $\begin{array}{c}52 \\
(65.00)\end{array}$ & $\begin{array}{c}42 \\
(52.50)\end{array}$ & $\begin{array}{c}94 \\
(58.75)\end{array}$ \\
\hline 7 & Social Participation & & & \\
\hline i. & No member of any organization & $\begin{array}{c}29 \\
(36.25)\end{array}$ & $\begin{array}{c}32 \\
(40.00)\end{array}$ & $\begin{array}{c}61 \\
(38.13)\end{array}$ \\
\hline ii. & Member of any organization & $\begin{array}{c}40 \\
(50.00)\end{array}$ & $\begin{array}{c}39 \\
(48.75)\end{array}$ & $\begin{array}{c}79 \\
(49.38)\end{array}$ \\
\hline iii. & Office bearer & $\begin{array}{c}11 \\
(13.75)\end{array}$ & $\begin{array}{c}9 \\
(11.25)\end{array}$ & $\begin{array}{c}20 \\
(12.50)\end{array}$ \\
\hline
\end{tabular}


Table.2 Distribution of respondents according to their level of adoption regarding groundnut Interventions

\begin{tabular}{|c|c|c|c|c|c|c|c|}
\hline \multirow[t]{2}{*}{ S. No. } & \multirow[t]{2}{*}{ Adoption Level } & \multicolumn{2}{|c|}{$\begin{array}{l}\text { Beneficiary } \\
\quad(\mathbf{n}=\mathbf{8 0})\end{array}$} & \multicolumn{2}{|c|}{$\begin{array}{c}\text { Non-beneficiary } \\
(\mathbf{n}=\mathbf{8 0})\end{array}$} & \multicolumn{2}{|c|}{$\begin{array}{c}\text { Total } \\
(\mathbf{n}=160)\end{array}$} \\
\hline & & $\mathbf{F}$ & $\%$ & $\mathbf{F}$ & $\%$ & $\mathbf{F}$ & $\%$ \\
\hline 1 & Low $(<26)$ & 14 & 17.50 & 19 & 23.75 & 33 & 20.62 \\
\hline 2 & $\begin{array}{l}\text { Medium } \\
\text { (Between } 26 \text { to 47) }\end{array}$ & 46 & 57.50 & 50 & 62.50 & 96 & 60.00 \\
\hline 3 & High $(>47)$ & 20 & 25.00 & 11 & 13.75 & 31 & 19.38 \\
\hline
\end{tabular}

Table.3 Extent of adoption of the beneficiary and non-beneficiary respondents regarding groundnut interventions

\begin{tabular}{|c|c|c|c|c|c|}
\hline \multirow[t]{2}{*}{ S. No. } & \multirow[t]{2}{*}{ Package of practices } & \multicolumn{2}{|c|}{$\begin{array}{l}\text { Beneficiary } \\
\quad(\mathbf{n}=80)\end{array}$} & \multicolumn{2}{|c|}{$\begin{array}{c}\text { Non-beneficiary } \\
\qquad(\mathbf{n}=\mathbf{8 0})\end{array}$} \\
\hline & & MPS & Rank & MPS & Rank \\
\hline 1. & Field preparation & 80.31 & IV & 76.25 & IV \\
\hline 2. & Soil treatment & 48.75 & $\mathrm{X}$ & 35.15 & $\mathrm{X}$ \\
\hline 3. & High yielding varieties & 100.00 & I & 100.00 & I \\
\hline 4. & Seed treatment & 77.19 & $\mathrm{~V}$ & 65.94 & VI \\
\hline 5. & $\begin{array}{l}\text { Time of sowing, seed rate and } \\
\text { spacing }\end{array}$ & 82.08 & III & 78.33 & II \\
\hline 6. & Manure and fertilizer application & 74.84 & VI & 67.03 & $\mathrm{~V}$ \\
\hline 7. & Irrigation management & 69.38 & VII & 53.13 & VIII \\
\hline 8. & Weed management & 58.33 & IX & 49.58 & IX \\
\hline 9. & Plant protection measures & 60.21 & VIII & 54.38 & VII \\
\hline 10. & Harvesting, threshing and storage & 84.06 & II & 78.13 & III \\
\hline & Overall & 73.52 & & 65.79 & \\
\hline
\end{tabular}


Table.4 Practices wise comparison between the beneficiary and non-beneficiary respondents about the adoption of groundnut interventions

\begin{tabular}{|c|c|c|c|c|c|c|}
\hline \multirow[t]{2}{*}{ S. No. } & \multirow[t]{2}{*}{ Package of practices } & \multicolumn{2}{|c|}{ Beneficiary $(n=80)$} & \multicolumn{2}{|c|}{ Non-beneficiary $(n=80)$} & \multirow{2}{*}{$\begin{array}{c}\text { 'Z' } \\
\text { Value }\end{array}$} \\
\hline & & Mean & SD & Mean & SD & \\
\hline 1 & Field preparation & 3.21 & 0.77 & 3.05 & 0.73 & $1.53^{\mathrm{NS}}$ \\
\hline 2 & Soil treatment & 8.29 & 8.55 & 5.98 & 8.14 & $1.96^{\mathrm{NS}}$ \\
\hline 3 & High yielding varieties & 12.00 & 0.00 & 12.00 & 0.00 & $\infty^{\text {NS }}$ \\
\hline 4 & Seed treatment & 9.26 & 2.71 & 7.91 & 4.11 & $2.74 * *$ \\
\hline 5 & $\begin{array}{l}\text { Time of sowing, seed rate, and } \\
\text { spacing }\end{array}$ & 4.93 & 0.79 & 4.70 & 0.75 & $2.06^{*}$ \\
\hline 6 & Manure and fertilizer application & 8.98 & 0.17 & 8.04 & 1.51 & $6.15^{* *}$ \\
\hline 7 & Irrigation management & 4.16 & 1.82 & 3.23 & 1.64 & $3.83^{* *}$ \\
\hline 8 & Weed management & 5.25 & 2.11 & 4.50 & 1.72 & $2.76^{* *}$ \\
\hline 9 & Plant protection measures & 10.84 & 4.39 & 7.79 & 4.72 & $4.73^{* *}$ \\
\hline 10 & Harvesting, threshing and storage & 3.36 & 0.80 & 3.13 & 0.85 & $2.04 *$ \\
\hline & Overall & 7.03 & 2.21 & 6.03 & 2.42 & $3.04 *:$ \\
\hline
\end{tabular}

NS $=$ Non-significant,$* *=$ Significant at $1 \%$ level of significance

These findings are in line with the findings of Pokar et al., (2014) found that majority of (92.86 per cent) beneficiary farmers and 81.42 per cent non-beneficiary farmers had medium to high level of adoption of demonstrated groundnut production technology among the respondents. Significant difference was found between beneficiary and non-beneficiary farmers with respect to their extent of adoption of demonstrated groundnut production technology. Similar findings are also reported by Subhashchand and Meena (2011) and Hadiya et al., (2014).

Practices wise comparison between the beneficiary and non-beneficiary respondents about the adoption of groundnut interventions

Table 4 indicates that calculated ' $Z$ ' value was greater than its tabulated value at a 1 percent level of significance in all practices of groundnut. Hence, the research hypothesis was accepted and the null hypothesis was rejected, which leads to the conclusion that there had been a significant difference in the level of adoption between the beneficiary and non-beneficiary respondents regarding recommended groundnut interventions. Further analysis of the Table shows that the mean score of beneficiary farmers is more than non-beneficiary farmers, which indicates that beneficiary farmers had more adoption level than non-beneficiary farmers about recommended groundnut interventions. This significant difference between the beneficiary and non-beneficiary respondents indicates that National Mission on Oilseed and Oil Palm played a significant and positive role in the adoption of various technologies of groundnut in the study area. Similar findings are reported by Pokar et al., (2014) and Patel et al., (2016).

Thus, from the above results, it may be concluded that majority of the respondents, belonged to middle age group, other backward castes, majority of the respondents in the category of senior secondary education level and respondents had a large size of land holding (more than $4 \mathrm{ha}$ ), belonged to joint families, and were from large families having more than five members, maximum number of respondents were member of any 
organization. It may also be concluded that beneficiary respondents had medium to high level of adoption while non-beneficiary respondents had medium to low level of adoption regarding recommended groundnut interventions.

It was also found that there was a significant difference between the beneficiary and nonbeneficiary respondents about the adoption of recommended groundnut interventions. This difference in the level of adoption of groundnut respondents might be because beneficiary respondents being in continuous touch with the field functionaries of National Mission on Oilseed and Oil Palm. Thus, they are more likely to practice the latest technical know-how.

\section{Recommendation}

The NMOOP mission under State Agriculture Department should give more emphasis to educate and trained the oilseed growers intensively about soil treatment, plant protection measures and weed control measures. This can be done by fixing the time bound training programmes and farmer's field school.

\section{References}

Asiwal, K. C. (2004) "Problems, prospectus and management of groundnut-wheat cropping system in Jaipur region of Rajasthan". Ph.D. (Ag.) Thesis (unpublished), Rajasthan Agricultural University, Bikaner, Rajasthan.

Hadiya, B., Deshmukh G. and Bariya, M. (2014) "Adoption of recommended practices of kharif groundnut growers in Saurashtra zone of Gujarat".Indian Research Journal Extension Education, 14(3):47-50.

Kumar, A. (2013) "Impact of Agricultural Technology Management Agency on Adoption of Mustard Production Technology by the Farmers in Alwar District of Rajasthan". M.Sc. (Ag.) Thesis (unpublished), Swami Keshwanand Rajasthan Agricultural University, Bikaner, Rajasthan.

Kumar, G.D.S. and Jain, V.K. (2011) "Impact of adoption of winter-summer groundnut production technology on livelihood of farmers".Journal of Oilseeds Research, 28(2): 131-136.

Patel, J.A., Desai, H.K., Prajapati, M.M. and Patel V.T. (2016) "Extent of adoption of kharif Groundnut production technology". International Journal of Agriculture Sciences, 8(36):1748-1751.

Pokar, M.V., Javia, R.M., Sapara, G.K. and Solanki, K.D. (2014) "Adoption of improved groundnut production technology under Front Line Demonstration". Agriculture Update,9(2): 186-189.

Raghuwanshi, V. (2018) "Study on Adoption of Organic Farming Practices in Soybean Crop in Guna District of Madhya Pradesh".Indian ResearchJournal of Extension Education, 18(4):18-22.

Salunkhe, S.R., Pandey, R.D., and Rai, S.K. (2012) "A study on personal, socio-economic, psychological and situational characteristics of agro-service providers and beneficiary in Gujarat state".Agricultureupdate.7(3\&4): 389393.

SubhashChand and Meena, K.C. (2011) "Correlates of adoption of Groundnut production technology by the farmers". Rajasthan Journal of Extension Education, 19: 125-127.

\section{How to cite this article:}

Amit Kumar, L.S. Bareth, J.P. Yadav, Manmeet Kaur and Ramdhan Ghaswa. 2019. Extent of Adoption of Recommended Interventions of Groundnut crop among the Beneficiary and Nonbeneficiary Respondents of National Mission on Oilseed and Oil Palmin Bikaner District of Rajasthan. Int.J.Curr.Microbiol.App.Sci. 8(08): 2254-2261.

doi: https://doi.org/10.20546/ijcmas.2019.808.261 